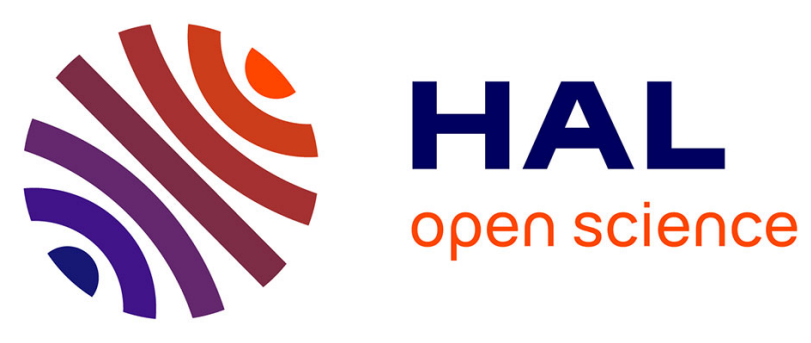

\title{
The imperfective in Berber
}

\author{
Mena B. Lafkioui
}

\section{To cite this version:}

Mena B. Lafkioui. The imperfective in Berber. Afroasiatic. Data and perspectives, pp.85 - 103, 2018, 10.1075/cilt.339.06laf . hal-01914352

\section{HAL Id: hal-01914352 https://hal.science/hal-01914352}

Submitted on 6 Nov 2018

HAL is a multi-disciplinary open access archive for the deposit and dissemination of scientific research documents, whether they are published or not. The documents may come from teaching and research institutions in France or abroad, or from public or private research centers.
L'archive ouverte pluridisciplinaire HAL, est destinée au dépôt et à la diffusion de documents scientifiques de niveau recherche, publiés ou non, émanant des établissements d'enseignement et de recherche français ou étrangers, des laboratoires publics ou privés. 


\section{John Benjamins Publishing Company}

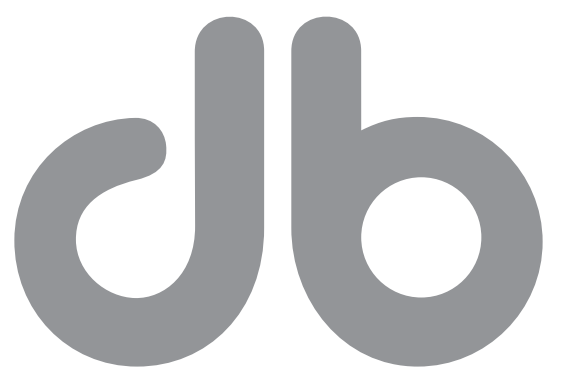

This is a contribution from Afroasiatic. Data and perspectives.

Edited by Mauro Tosco.

(c) 2018. John Benjamins Publishing Company

This electronic file may not be altered in any way.

The author(s) of this article is/are permitted to use this PDF file to generate printed copies to be used by way of offprints, for their personal use only.

Permission is granted by the publishers to post this file on a closed server which is accessible to members (students and staff) only of the author's/s' institute, it is not permitted to post this PDF on the open internet.

For any other use of this material prior written permission should be obtained from the publishers or through the Copyright Clearance Center (for USA: www.copyright.com). Please contact rights@benjamins.nl or consult our website: www.benjamins.com Tables of Contents, abstracts and guidelines are available at www.benjamins.com 


\title{
The imperfective in Berber
}

\section{Evidence of innovated forms and functions}

\author{
Mena Lafkioui \\ Llacan-CNRS/Université Sorbonne Paris Cité
}

This article analyzes the morphological oppositions and semantic distinctions that originate from transformation processes regarding the imperfective in Berber. The synchronic and diachronic phenomena studied in this contribution offer examples of how language is continually modulated through innovations that emerge in structurally layered and causal formations dictated by system-based properties.

Keywords: imperfective, comparative Berber, morphological verbal innovation, semantic diversification, diachronic verbal development, system-internal language change

\section{Introduction}

This study addresses several morphological innovation processes of the Berber verbal system driven by linguistic (formal and functional) parameters. It focuses on how these transformations affect morphological oppositions and related semantic thematic distinctions, at both a synchronic and a diachronic level. In doing so, I offer evidence that confirms the importance of system-internal induced language variation and change. ${ }^{1}$

1. The following abbreviations are used in this article: A 'aspect(ual)', ACC 'accusative', AOR 'aorist', DIST 'distal', IMP 'imperative', NIMP 'negative imperative', IPFV 'imperfective', INT 'intonation', M 'masculine', MOD 'modality', NEG 'negation', NIPFV 'negative imperfective', NPFV 'negative perfective', NOM 'nominative', o 'object', PFV 'perfective', PL 'plural', PRSM 'personal marker', PTCP 'participle', Ртсрм 'participle marker', s 'subject', sG 'singular', v 'verbal syntagm', + 'marked', 'unmarked'. The original transcription of the cited Berber examples is maintained. Examples from my own corpus are transcribed according to the general Berber phonological system and to IPA. All English glosses of the Berber examples are my own. 
The current Berber verbal system is based on a fundamental morphological opposition of perfective versus imperfective for the positive aspects and perfective versus negative perfective for the negative aspects (Basset 1952; Chaker 1989; Galand 1977; Lafkioui 2007: 174-191). Tuareg, which is mostly spoken in the Sahara area, and Tarifit, mainly spoken in northern Morocco, differ considerably from this basic system in that they have developed a series of secondary morphological verbal oppositions which mark distinctive semantic values (Lafkioui 2007: 174-191; Lafkioui \& Kossmann 2009; Leguil 1987, 2000; Prasse \& ăgg-Ălbostan ăgg-Sidiyăn 1985; see Figure 1, dark grey zones). Although both languages show derivational mechanisms generating these new variants, there is a significant difference between them with respect to the precise transformation processes involved and the corresponding reorganization of the verbal paradigmatic structure. These phenomena will be discussed in detail in the ensuing sections.

From a typological perspective, the Berber languages, belonging to the Afroasiatic phylum, are predominantly synthetic (inflection, derivation and compounding) and inflecting. Common features are their VSO base word order, their pro-drop feature (i.e., verbal constructions obligatorily contain an incorporated subject marker), their preposition-noun sequence, their possessive suffixes and their mixed morphological plural formation (affixation and/or apophony). Aside from noun-verb oppositions, all other word class distinctions are unclear in Berber. The Berber languages also provide accounts of one of the indisputably typological linguistic features of Africa. This is the marked-nominative, a feature which is barely attested outside Africa but is present in most case languages within it, including those of East Africa (König 2006; Lafkioui forthcoming). In these systems, it is the nominative that is functionally marked with reference to the accusative, even if the languages in question may differ as regards the morphosyntactic marking procedures.

For example in Tamazight Berber (central Morocco), we find:

(1) i-ča urgaz aǵrum

eat-PFV-3MSG man-NOM bread-ACC

"The man ate bread."

The nominative is encoded by the morphological marker $u$ - (dependent state marker) and a continuous intonation unifying the noun with the preceding verbal syntagm, while the accusative is encoded by the absence of these morphemes and so matches the unmarked form; i.e., $a$ - (accusative, independent state) versus $u$ (nominative, dependent state).

This work is part of the program "Investissements d'Avenir" overseen by the French National Research Agency, ANR-10-LABX-0083 (Labex EFL)

(C) 2018. John Benjamins Publishing Company

All rights reserved 
An examination of the Berber verbal system follows this introduction $(\$ 2)$. In $₫ 3$, the negative imperfective and its specific features are considered. $\$ 4$ analyzes the innovations of the Tuareg and Tarifit verbal system, with a focus on the morphology-semantics interface. The article ends with a number of conclusions about language variation and its connection with language evolution.

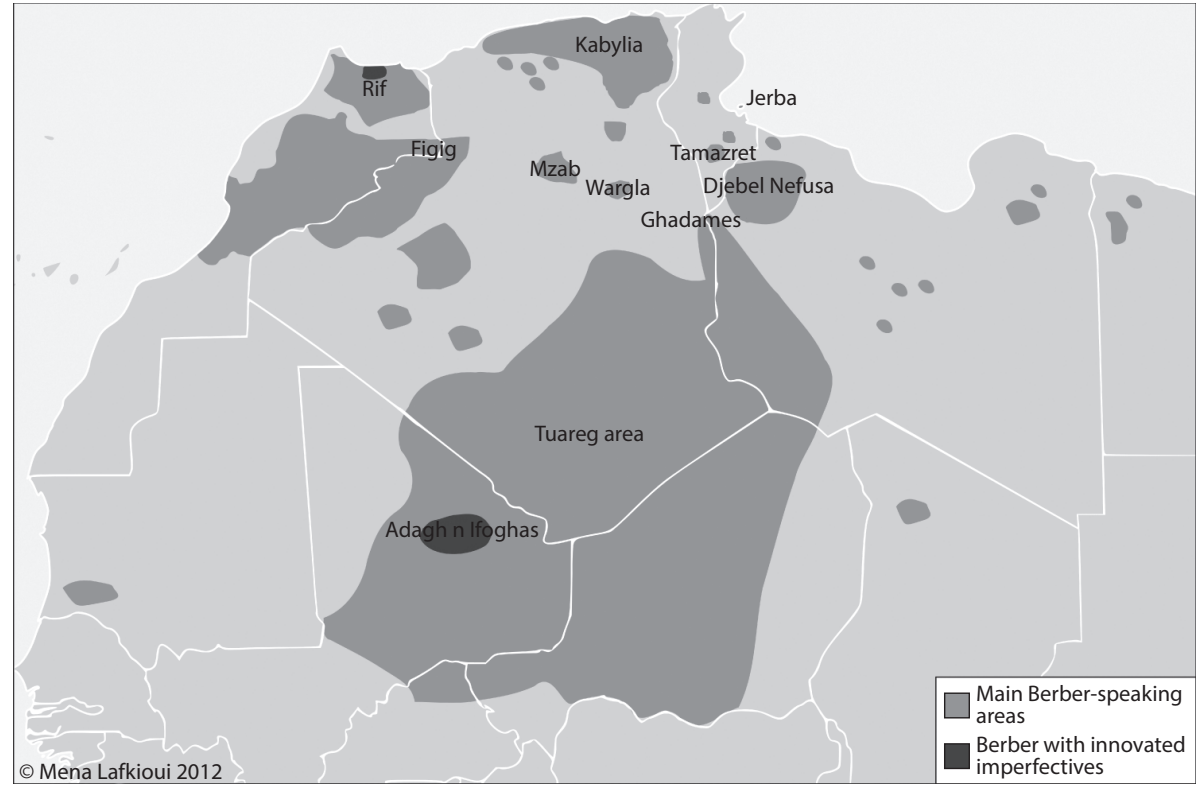

Figure 1. Berber areas with innovated imperfectives

\section{The Berber verbal system}

The Berber verbal system is of a Root-Pattern type. It is structured around a complex aspectual hierarchical configuration of three levels, which are structurally more complex and semantically more specific as one ascends the hierarchy. It displays a predominance of tri-radical roots and makes use of both consonant length and intra-radical vowel alternation (apophony) to indicate aspectual categories. From a synchronic perspective, the Berber verbal form is composed of a stem and a personal marker (PRSM) or participle marker (PTCPM). The stem itself consists of a consonantal root, which refers to a central semantic value, and a vowel pattern that orientates or specifies this value:

1. Verb $=$ stem + person or participle marker (highest level)

2. Stem $=$ root + vowel pattern (middle level)

3. $\quad$ Root $=$ consonantal radicals (basic level)

(C) 2018. John Benjamins Publishing Company

All rights reserved 
Examples of verbal forms:

(2) $y$-udf [juðəf] "he has entered" (PFV-3MSG) = PRSM $y$ - (3MSG) + stem - udff

(3) $y$-udf-n [juðfən] "has/have entered" (PFV-PTCP) = РтСРм $y-e n+$ stem - $u \underline{d f}$ -

$\Rightarrow$ Stem: $u \underline{d} f[\mathrm{~J} \partial ə \mathrm{f}]=\operatorname{root} / \underline{\mathrm{d} f} /$ (action "to enter") + pattern /u--/ (PFV)

$\Rightarrow$ Bi-radical root: /cc/ with / $\mathrm{d} /[\mathrm{\gamma}]$ and /f/ [f] as radicals (action "to enter")

Stem and person/participle markers are inevitably connected in the verbal syntagm; the former functions as predicate and the latter as subject. The subject marker is encoded on the verb as a prefix and/or a suffix and is made explicit by postverbal lexical complements with specific features, e.g., dependent state. The V(erb)$\mathrm{S}$ (ubject) syntagm represents the minimal required structure of an assertion, which is expanded by an object $(\mathrm{O})$ in the case of transitive verbs and various other complements insofar as the morphosyntactic adequacy and the semantic sufficiency of the verbal stem permit, with a VSO basic word order.

The contemporary Berber verbal system is based on a fundamental morphological opposition of perfective (PFV) versus imperfective (IPFV) for the positive aspects and perfective (PFV) versus negative perfective (NPFV) for the negative aspects (Basset 1952; Galand 1977; Cadi 1987: 59-65; Chaker 1989; Lafkioui 2007: 174-191). Consequently, Berber disconfirms the cross-linguistic claim that the perfective is less compatible with negation than the imperfective (Schmid 1980: 39; Matthews 1990: 84).

Table 1. Basic verb oppositions in Berber

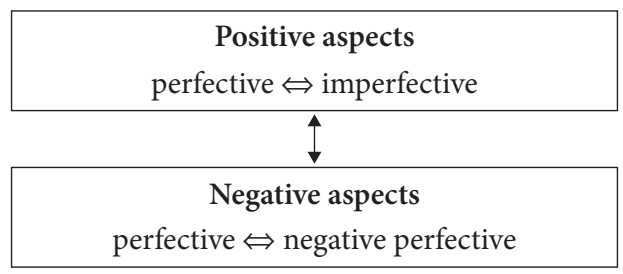

Regarding the positive aspects, the following diachronic reconstruction, based mainly on Galand's hypothesis (1977, 2002: 259-271), may well explain the various phenomena presently attested in the different Berber languages:

1. On a Proto-Berber level (stage I), the opposition [aorist (unmarked) perfective (marked)] existed and initiated the evolution process that has led to the present system. The neutral aorist stood for modal values as well as for aspectual values, whereas the perfective only rendered aspectual values.

2. In stage II, still on a Proto-Berber level, derivational devices (e.g., $t(t)$ - affixation, radical gemination and vowel insertion) - which later changed into aspectual markers - signaled the emergence of a new verbal theme, the imperfective, which took over the aspectual values of the aorist and, consequently, (C) 2018. John Benjamins Publishing Company

All rights reserved 
Table 2. Diachronic reconstruction of the positive thematic oppositions in Berber

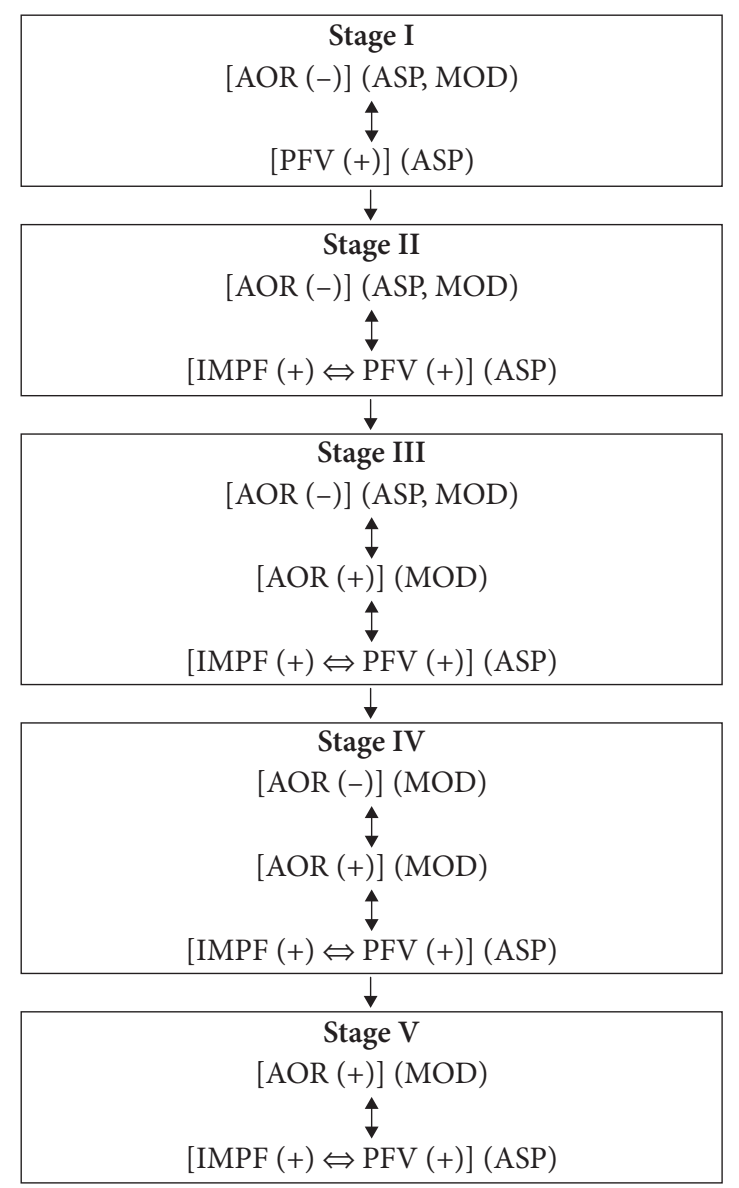

entered into opposition with the perfective: [aorist (unmarked) \{imperfective (marked) perfective (marked)\}]. The newly created imperfective mainly signified habituation and progression.

3. Stage III is presently attested in diverse Berber languages, such as Tashelhit (southern Morocco), Tamazight (central Morocco) and western Tarifit (also called Senhaja Berber, northern Morocco). It consists of the development of a marked aorist by means of a periphrastic marker, i.e., modality particle. The unmarked aorist is retained for specific functions, like, for instance, to express injunctions and to mark concatenation. The modality particle can also be combined with the imperfective, generating a double marking system (i.e., aspectual and modal marking) and, hence, signifying layered values. This stage could be summarized as follows: [aorist (unmarked) \{aorist (marked) imperfective (marked) perfective (marked) $\}]$.

(C) 2018. John Benjamins Publishing Company

All rights reserved 
4. In Stage IV, the aorist has lost some of its unmarked non-modal functions, although these are generally preserved in literary practices. This language phase is best represented by, for instance, Kabyle Berber (northern Algeria), Tuareg Berber, and eastern Tarifit (northern Morocco).

5. The last stage (stage V) is characterized by the loss of the 'bare' aorist so that only the marked thematic forms remain; that is, [aorist (marked) imperfective (marked) perfective (marked)]. This thematic evolution is principally observed in the more Eastern Berber languages, such as the Berber language of Nefusa in north-western Libya.

As to the negative aspects, most scholars of Berber agree that these aspectual forms were derived from positive themes tracing back to Proto-Berber times, but there is no general consensus as to the exact triggers and processes. Nonetheless, two interesting tendencies regarding this phenomenon should be mentioned here. The first tendency considers the emergence of the negative aspects as a consequence of the development of an 'intensive' variant of the existing themes (e.g., intensive aorist $\Rightarrow$ imperfective; intensive perfective $\Rightarrow$ resultative), which subsequently would have been reanalyzed as a negative theme, particularly in the case of the negative perfective (Chaker 1996; Picard 1959; Prasse 1973). The second one regards this ancient innovation as the ultimate outcome of a phonetic transformation process triggered by the presence of a post-verbal negation marker (Brugnatelli 2002; Vycichl 1953-1955: 322). The enclitic negator would have provoked a shift in stress towards the final syllable position, which would have engendered the series of features that, at present, mark negative verbal forms in Berber, namely a shortened initial syllable or syllable group, a lengthened final syllable or syllable group and an umlaut of the vowel $i$.

\section{The negative imperfective in Berber}

A number of Berber languages have a morphologically marked negative imperfective (NIPFV) which is used in negation contexts. This is the case, for example, for Berber spoken in Figig, the Rif area, Ghadames, Jerba, Tamazret, Wargla, Mzab and the Tuareg areas (see Figure 1). However, most of the Berber languages make use of the positive imperfective in both positive and negative configurations. Given its similar marking and functional procedures in a wide range of Berber languages spread over the whole of North Africa, it is most likely that the negative imperfective is a remnant of a verbal theme in Proto-Berber (Brugnatelli 2002; Chaker 1996: 18; Kossmann 1989). Other evidence supporting this hypothesis is that those languages which lack the negative imperfective in their daily language 
practices do, however, exhibit its use in ancient or literary texts, such as the medieval text in Tashelhit (southern Morocco) of Mhemmed Awzal (Van den Boogert 1997: 270) or the Kabyle expression of northern Algeria as in Example (4) (see also Brugnatelli 2002):

(4) ur i-ţudeggir

(Mammeri 1980: 234)

NEG shake-NIPFV-3MSG

"He will not be shaken."

The negative imperfective is generally marked by an apophonic modification, that is, the full (unreduced) vowel $a$ is changed into the vowel $i:[a>i]$ (5)-(7). However, the vowel $a$ is maintained as such in the negative imperfective form when the corresponding $a$ of the positive imperfective form is preceded by the vowels $i$ or $u$, as in (8) and (9):
(5) i-ttad $\partial f$ enter-IPFV-3MSG
(6) $y \partial-\check{c} \check{c} a \underline{t}$

$$
\begin{aligned}
\Leftrightarrow & u \quad y \text { - } \text {-čćit } \quad \check{s} \\
& \text { NEG beat-NIPFV-3MSG NEG } \\
& \text { "He does/will not beat." }
\end{aligned}
$$
"He beats."
(7) yo-ssawar

$$
\begin{aligned}
& \Leftrightarrow w a \quad y \text {-ssiwir } \quad \check{s} a \\
& \text { NEG } \text { speak-NIPFV-3MSG NEG } \\
& \text { "He does/will not speak." }
\end{aligned}
$$
speak-IPFV-3MSG
(8) i-ttilaz
be hungry-IPFV-3MSG
$\Leftrightarrow u l \quad$ i-ttilaz
NEG be hungry-IPFV-3MSG NEG
"He is always hungry."
(9) yə-tzuzzar
"He will not be hungry."
winnow-IPFV-3MSG
$\Leftrightarrow w a \quad y$-tzuzzar
$\check{s} a$
NEG winnow-IPFV-3MSG NEG
"He winnows."
"He does/will not winnow."

(Figig)

Beside apophonic change, Tuareg Berber also marks the negative imperfective by shortening the first vowel of the stem (10) or by a lengthening of its last vowel (11):
(10) i-lâss
$\Leftrightarrow[w a r]$ i-less
dress-IPFV-3MSG
NEG dress-NIPFV-3MSG
(Tuareg; Prasse
"He dresses himself."
"He does/will not dress himself."
1973: 109)
(11) i-tâkär
$\Leftrightarrow[$ war $]$ i-tiker
NEG steal-NIPFV-3MSG
"He does/will not steal."
(Tuareg; Prasse
1973: 96)
"He steals." 
In contrast to the positive imperfective, the negative imperfective necessarily occurs in a negation context. The only exception to this rule is the negative imperative, i.e., the interdiction, in which a 'positive' form is employed after a negation marker, such as in Example (12), which comes from Jerba but occurs in Tarifit as well:

$$
\begin{array}{ll}
\begin{array}{l}
\text { ruh } \\
\text { go-IMP-2sG } \\
\text { "Go!" }
\end{array} & \begin{array}{l}
\text { yo-trah } \\
\text { go-IPFV-3MSG } \\
\text { "He goes." }
\end{array}
\end{array} \Leftrightarrow \begin{array}{lll}
u & \text { trah } & \text { NEG go-IMP-2sG NEG } \\
\text { "Do not go!" }
\end{array}
$$

Nevertheless, some Berber varieties of the Rif area (northern Morocco) - especially of its eastern and western part - make use of both imperfective forms to render an interdiction (Lafkioui 2007: 176). For example, the Ayt Iznasen and the Ikebdanen (eastern Rif) employ the following expression:
ur qqir
šayt amanni
NEG say-NIMP-2SG NEG so
"Do not speak like that!"

The corresponding positive form of qqir ( < ini "say") in Example (13) is qqar. In the varieties of the Ayt Itteft (border western and central Rif), on the other hand, a free alternation between the positive form (14) and the negative form (15) is observed in interdictions:

$$
\begin{aligned}
& \text { u tižža } \quad m m i=m \quad \underline{d i n} \\
& \text { NEG leave-IMP-2SG son=3MSG DIST } \\
& \text { "Do not leave your son there!" } \\
& u \quad t i \check{z} z ̌ i \quad m m i=m \quad \text { din } \\
& \text { NEG leave-NIMP-2sG son=3MSG DIST } \\
& \text { "Do not leave your son there!" }
\end{aligned}
$$

\section{Innovations in the Berber verbal system}

Even though Tuareg and Tarifit share a comparable system-based innovating apparatus regarding the verb, they are clearly dissimilar with respect to the derivational transformations and the related formal and functional restructuring of the paradigms in question, as will be demonstrated in the next two sections. While the Tuareg case has already been examined to some extent - though further investigation is still required - the Tarifit innovations have never been the subject of a thorough study, especially from a comparative viewpoint. In what follows, both innovated systems will be addressed and compared so as to better understand the complex evolution process of the Berber verb. A starting basis for the Tarifit study 
has been presented in Lafkioui (2007: 175-176) and Lafkioui \& Kossmann (2009). As for Tuareg, I mainly refer to the studies of Leguil $(1987,2000)$ and Prasse \& ăgg-Ălbosțan ăgg-Sidiyăn (1985).

\subsection{Innovations in the Tuareg verb}

The Tuareg language of Mali displays secondary morphological oppositions for the positive perfective (PFV) as well as for the positive imperfective (IPFV), which were historically derived from original sets of variants. Most of the Tuareg languages have lost the original imperfective and just use the innovated one. But a number of varieties in Mali have retained the opposition between the two types of positive imperfectives, as shown in Table 3.

Table 3. Verb alməd "to learn” (Adagh of Ifoghas - Mali, Prasse \& ăgg-Ălbostan ăgg-Sidiyăn 1985)

\begin{tabular}{lll}
\hline & Original variants & Secondary variants \\
\hline Aorist & almad & - \\
Positive perfective & almăd & almád \\
Negative perfective & almed & - \\
Positive imperfective & lămmăd & lámmăd \\
Negative imperfective & lamməd & - \\
\hline
\end{tabular}

The derivational mechanism of these developments is based on a modification of the stem vowel (called lengthening) and an insertion of a fixed stress accent (Heath 2005: 299 ff.; Leguil 2000):

$-a>i$

$-a>u$

$-\quad \breve{a}>a$

The modification rules $a>i$ and $a>u$ are mutually exclusive and are mostly predictable on the basis of the preceding long vowel.

Regarding the perfective, the Tuareg languages belong to the few Berber languages that have developed a resultative from the positive perfective by means of a vowel lengthening and a stable accent placement (see Table 3; for details, see Galand 1974; Heath 2005; Prasse 1973).

As to the imperfective, its diachronic evolution could be explained through a six-step process, in which the Adagh varieties of Mali have reached Stage V, whereas the other Tuareg varieties have got to the final stage - that is, the stage in which the opposition between the original variants and their secondary developments has disappeared. 
1. Based on Leguil's (2000) accounts, this diachronic analysis starts with a one-part structure with no axiological opposition between its habitual and progressive values. This stage (Stage I) is still observed in the Berber language of Ghadames (Libya). ${ }^{2}$

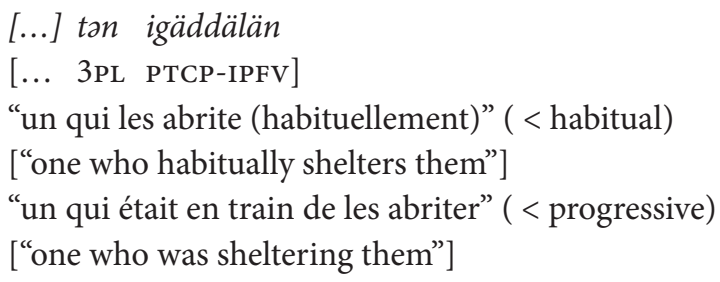

2. Stage II, attested in Tuareg, is characterized by a variable opposition in which a new imperfective marked by a long vowel represents the progressive, while the original unmarked imperfective stands for both progressive and habitual values:

$$
\begin{aligned}
& \text { [...] tวn igyäddälän } \\
& \text { [... 3PL PTCP-IPFV] } \\
& \text { "un qui les abrite (habituellement)" } \\
& \text { ["one who habitually shelters them"] } \\
& \text { "un qui était en train de les abriter" } \\
& \text { ["one who was sheltering them"] }
\end{aligned}
$$

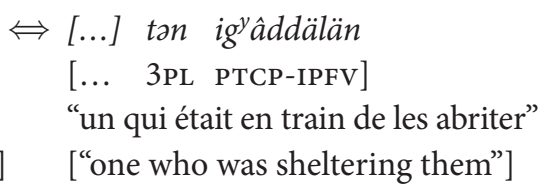

3. In Stage III, the innovated imperfective in Tuareg has entirely claimed the progressive, which has left the original form with just the habitual. This development has resulted in a bipartite marked opposition, as demonstrated in (18).

$$
\begin{array}{lll}
{[\ldots] \tan \text { igyäddälän }} & {[\ldots] \text { tan igyâddälän }} \\
\text { [... 3PL PTCP-IPFV] } & {[\ldots \text { 3PL PTCP-IPFV] }} \\
\text { "un qui les abrite (habituellement)" } & \text { "un qui était en train de les abriter" } \\
\text { ["one who habitually shelters them"] } & \text { ["one who was sheltering them"] }
\end{array}
$$

4. Again, a variable opposition between the two imperfectives is observed in Tuareg Berber (Stage IV), but this time their markedness is inverted. The original short form is marked and signifies the habitual. The new long form, on the other hand, is unmarked and expresses the habitual as well as the progressive:

2. Unfortunately, Leguil (2000) does not specify the exact Tuareg varieties that are subject to the changes explained in stages II, III and IV. Further investigation based on fieldwork in the area is needed in order to get a better understanding of the phenomena at hand. 
(19)

$$
\begin{aligned}
& {[\ldots] \text { tan igÿäddälän }} \\
& {[\ldots \text { 3PL PTCP-IPFV] }} \\
& \text { "un qui les abrite (habituellement)" } \\
& \text { ["one who habitually shelters them"] }
\end{aligned}
$$

$$
\begin{aligned}
& \Leftrightarrow[\ldots] \text { tan igŷâddälän } \\
& {[\ldots \text { 3PL PTCP-IPFV] }} \\
& \text { "un qui était en train de les abriter" } \\
& \text { ["one who was sheltering them"] } \\
& \text { "un qui les abrite (habituellement)" } \\
& \text { ["one who habitually shelters them"] }
\end{aligned}
$$

5. Stage $\mathrm{V}$ is that of the Ifoghas Tuareg of Mali, which provides evidence of a new equipollent opposition with marked modal values instead of marked aspectual values, since both the habitual and the progressive are associated only with the innovated imperfective (i.e., non-modal values):

$$
\begin{array}{lc}
{[\ldots] \text { tan igÿ̈̈dälän }} & \Leftrightarrow[\ldots] \text { tan igyâddälän } \\
\text { [... 3PL PTCP-IPFV] } & {[\ldots \text { 3PL PTCP-IPFV] }} \\
\text { "un qui est apte à les abriter" } & \text { "un qui était en train de les abriter" } \\
\text { ["one who is capable of sheltering } & \text { ["one who was sheltering them"] } \\
\text { them"] } & \text { "un qui les abrite (habituellement)" } \\
& \text { ["one who habitually shelters them"] }
\end{array}
$$

6. The last stage (Stage VI) has lost the modal opposition and is thus similar to the departure stage where one form - in this case, the innovated imperfective - conveys both aspectual values. This stage represents most of the present Tuareg languages:

$$
\begin{aligned}
& \text { (21) [... tan igyâddälän } \\
& {[\ldots \text { 3PL PTCP-IPFV] }} \\
& \text { "un qui était en train de les abriter" } \\
& \text { ["one who was sheltering them"] } \\
& \text { "un qui les abrite (habituellement)" } \\
& \text { ["one who habitually shelters them"] }
\end{aligned}
$$

\subsection{Innovations in the Tarifit verb}

Compared to the other Berber languages, Tarifit (i.e., Central Tarifit) has a remarkable formation system for the imperfective. Two major characteristics are observed:

1. There are various innovated positive imperfectives associated with corresponding negative imperfectives, all standing for different semantic values which comprise axiological oppositions.

2. There is a morphological-semantic opposition between the positive imperfectives and the negative imperfectives within negation configurations. 
These properties are at the basis of a considerable system enhancement that has brought its imperfectives to a total of six, compared to generally one or two imperfectives in the other Berber languages.

Table 4. The imperfectives of Central Tarifit (ex. ad $\partial f$ "to enter", 3MSG)

\begin{tabular}{|c|c|}
\hline Positive context & Negative context \\
\hline$i$-ttadof & uri-ttadəf \\
\hline- & $u r i-t t i \underline{d} \partial f$ \\
\hline$i$-ttadaf & ur i-ttadaf \\
\hline- & ur i-ttidif \\
\hline
\end{tabular}

The thematic oppositions in question were developed from the progressive imperfective (imperfective type A, IPFva; see Table 5) which, in Berber, is commonly constructed by means of the following morphological procedures:

- a gemination or tenseness of the first or second verbal radical;

- an affixation of the proclitic $t t$ - (mainly before vowels) or $t$ - (mainly before consonants);

- an insertion of a full vowel before or after the final consonant of the stem; i.e., vowel $a$ or a repetition of the preceding vowel.

These morphological derivation devices are, however, subject to the following combinatorial restrictions:

- gemination/tenseness and prefixing of $(t) t$ - are usually not combined;

- prefixing of $(t) t$ - is mainly associated with vowel insertion;

- the combination of gemination/tenseness and vowel insertion is allowed in IPFVa for verbs of the /cc/ and /ss-icc/ type: e.g., gaz (AOR) qqaz (IPFVa) "to dig" (see also Table 5).

Regarding the secondary imperfectives (IPFVb and IPFVC), these are derived from IPFVa and are developed by means of morphological combinations drawing on the same procedures used for IPFVa (see Table 5); that is:

- prefixing $(t) t$ - to IPFVa (imperfective B, IPFVb);

- inserting the vowel $a$ before the final consonant of the IPFvb stem (imperfective C, IPFVC).

As shown in Table 5, imperfectives b and $\mathrm{c}$ can only be formally derived from imperfectives which are not already supplied with the $(t) t$ - prefix or the $a$ vowel (in all stem positions). In such cases, the imperfective oppositions are neutralized. Most of the verbs concerned are transitive or labile (i.e., they show interchangeability of arguments; also called 'symmetric' verbs in Berberology). In the case of 
Table 5. Positive imperfective oppositions in different verb types

\begin{tabular}{|c|c|c|c|c|c|}
\hline Type & AOR & IPFVa & IPFVb & IPFVC & Translation \\
\hline cc:c & mallag & tmallag & $=$ IPFVa & $=$ IPFVa & "to joke" \\
\hline $\mathrm{ac}$ & af & ttaf & $=$ IPFVa & $=$ IPFVa & "to find" \\
\hline cac: & darr & tdiarra & $=$ IPFVa & $=$ IPFVa & "to harm" \\
\hline cc: & badd & tbadda & $=$ IPFVa & $=$ IPFVa & "to stand up" \\
\hline $\operatorname{cc}(1)$ & $n \partial \dot{g}$ & naqq & tnaqq & $=\mathrm{IPFVb}$ & "to kill" \\
\hline $\operatorname{cc}(2)$ & $\dot{g} \partial z$ & $q q a z$ & $\operatorname{tqaz}$ & $=\mathrm{IPFVb}$ & "to dig" \\
\hline $\mathrm{cca}$ & fna & fanna & tfanna & $=\mathrm{IPFVb}$ & "to die" \\
\hline ac:c & $a z z a r$ & ttazzər & $=$ IPFVa & ttazzar & "to run" \\
\hline acc & $a d \partial f$ & ttadof & $=$ IPFVa & ttadaf & "to enter" \\
\hline$s s$-icc & ssiwat. & $s s a k k^{w}$ ad & tsakk ad & $=\mathrm{IPFVb}$ & "to bring" \\
\hline $\mathrm{ccc}$ & $d f \partial s ̦$ & tđaffoṣ & tđ̣̂ffoș & tḍ̂ffaṣ & "to fold" \\
\hline
\end{tabular}

a labile verb, it is its transitive dimension that is subject to the innovation process; e.g., ssfa (AOR) ("to be pure") șaffa (IPFVa)/tșaffa (IPFVb)/tșaffa (IPFVc) ("to be pure"/"to purify").

Furthermore, a number of verbs in Central Tarifit allow for the existence of even four positive imperfectives, such as, for instance, the verb ftar ("to tress", "to roll couscous", "to wreathe").

Table 6. The verb "to roll couscous" and its four positive imperfective forms

\begin{tabular}{ll}
\hline & "to roll couscous" \\
\hline Aorist & ftar \\
Imperfective A & fattar \\
Imperfective B & tfattar \\
Imperfective C & tfattar \\
Imperfective D & fattar \\
\hline
\end{tabular}

However, these morphological oppositions do not usually occur in verbal forms of the /c:c/ type, where they might be most expected; e.g., the form ${ }^{\star}$ takkas is not attested as a variant of the regular forms $k$ kas (AOR) takkas (IPFV) "to take away". They are mainly found in verbs of the /ccc/ type, as exemplified in Table 6, which is the most generalized verbal template in Berber. In addition, the semantic values of the imperfective $\mathrm{D}$ are variable and hence difficult to pinpoint, although they generally convey notions similar to those expressed by means of the imperfective $\mathrm{C}$ (see Table 8 and corresponding examples). As regards the negative imperfective, these are the oppositions that correspond to the positive imperfectives presented in Table 5. 
Table 7. Negative imperfective oppositions in different verb types

\begin{tabular}{|c|c|c|c|c|c|}
\hline Type & AOR & NIPFVa & NIPFVb & NIPFVc & Translation \\
\hline $\mathrm{cc:c}$ & mallag & tmallig & $=$ NIPFVa & $=$ NIPFVa & "to joke" \\
\hline $\mathrm{ac}$ & af & ttif & $=$ NIPFVa & $=$ NIPFVa & "to find" \\
\hline cac: & darr & tđạarri & $=$ NIPFVa & $=$ NIPFVa & "to harm" \\
\hline cc: & badd & tbaddi & $=$ NIPFVa & $=$ NIPFVa & "to stand up" \\
\hline $\mathrm{cc}(1)$ & $n \partial \dot{g}$ & naqq & tnaqq & $=$ NIPFVb & "to kill" \\
\hline $\mathrm{cc}(2)$ & $\dot{g} \partial z$ & $q q i z$ & tqiz & $=\mathrm{NIPFVb}$ & "to dig" \\
\hline $\mathrm{cca}$ & fna & fanni & tfanni & $=$ NIPFVb & "to die" \\
\hline ac:c & $a z z \partial r$ & ttizzar & $=$ NIPFVa & ttizzir & "to run" \\
\hline acc & $a d \partial f$ & ttid $\partial f f$ & $=$ NIPFVa & ttidif & "to enter" \\
\hline$s s$-icc & ssiwad & $s s i k k^{w} i d$ & $t s i k k^{w} i d$ & $=$ NIPFVb & "to bring" \\
\hline $\mathrm{ccc}$ & $d f \partial s \underline{s}$ & dִfffaș & tđ̣̂ffaș & tđ̣̂ffiș & "to fold" \\
\hline
\end{tabular}

Every full vowel $a$ of the IPFV is replaced by $i$ in the corresponding negative form (except /cac:/ verb type). Verbs ending with ${ }^{\star} a r$, e.g., *akar "steal", have no distinctive forms for the IPFV, because the opposition between $\left[\bar{a}<{ }^{*} \partial r\right]$ and $\left[\bar{a}<{ }^{*} a r\right]$ is neutralized here due to the vocalization of $r$ (Lafkioui, 2006, 2007, 2009, 2011). In negation contexts, however, this opposition is marked:

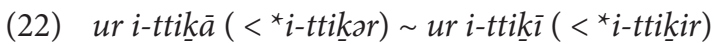

From a functional perspective, both the original and the innovated imperfectives in Central Tarifit express semantic distinctions which have not usually become possible as a result of thematic change in the other Berber languages, as is demonstrated in Examples (23)-(25).

(23) i-kֵannaf izumbiyyan.

grill-IPFVa-3MSG corn-MPL

"He is grilling corn cobs."

(24) kur țmaddiț(,) i-tkannaf izumbiyyan.

every evening + INT grill-IPFvb-3MSG corn-MPL

"Every evening, he grills corn cobs."

(25) i-tk̇nnaf izumbiyyan.

grill-IPFVC-3MSG corn-MPL

"He is used to grilling corn cobs."

Table 8. Semantic distinctions of the imperfective in central Tarifit

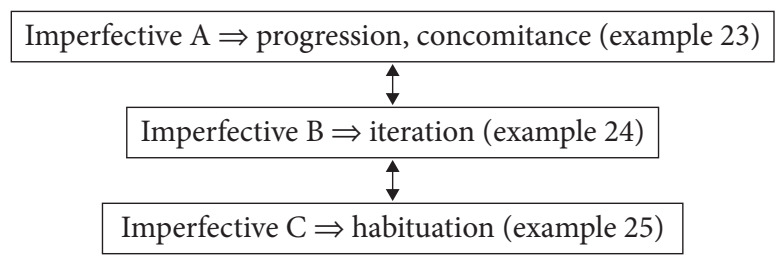

(C) 2018. John Benjamins Publishing Company

All rights reserved 
These morphological oppositions of the imperfective not only have a high functional productivity in Tarifit, but also indicate distinctive semantic values. (26) and (27) corroborate this and show how a morphological neutralization implies an axiological neutralization:

i-ttağam ssin.

draw up water-IPFVa/IPFvb-3MSG from there

"He draws up water from there."

"He is drawing up water from there."

(27)

i-ttagam ssin.

draw up water-IPFVC-3MsG from there

"He is used to drawing up water from there."

"He always draws up water from there."

"He is always drawing up water from there."

Another remarkable feature of central Tarifit is the use of positive perfectives (A, $\mathrm{B}, \mathrm{C})$ in negation structures after a negation marker such as $u r$, in order to create new oppositions. The precise semantic values of these innovated oppositions are difficult to define for the time being because of their variable nature, but their principal properties cover the values described in Table 9.

Table 9. Semantic distinctions of positive imperfectives in negation

\begin{tabular}{|cl|}
\hline $\begin{array}{c}\text { Punctual verbs } \\
\text { NEG+IMPF }\end{array}$ & $\Rightarrow$ habitual \\
NEG+NIMPF & $\Rightarrow$ non-habitual \\
\hline $\begin{array}{c}\text { Non-punctual verbs } \\
\text { NEG+IMPF }\end{array}$ & $\Rightarrow$ durative (intensity) \\
NEG+NIMPF & $\Rightarrow$ non-durative \\
\hline
\end{tabular}

In (28)-(31), I present a series of examples, based on the punctual verb aḡar "to hang up", that account for these formal-functional oppositions:

ur i-ttaḡar ši azğa $\underline{a}=i n \partial s$.

NEG hang up-IPFVa/IPFVb-3MSG NEG djellaba=3MSG

"He is not used to hanging up his djellaba."
ur i-ttaḡar
ši azğab $\underline{a}=i$ inวs.
NEG hang UP-IPFVC-3MSG NEG djellaba=3MSG
"He is not used to always hang up his djellaba."
ur i-ttiḡar
ši azğab $=i n \partial s$.
NEG hang up-NIPFVa/NIPFVb-3MSG NEG djellaba=3MSG
"He does not hang up his djellaba."
"He will not hang up his djellaba."

(C) 2018. John Benjamins Publishing Company

All rights reserved 
(31)
ur i-ttigir
ši $a z g \check{a} a b=i n \partial s$.
NEG hang up-NIPFVc-3MSG NEG djellaba $=3$ MSG
"He does not hang up his djellaba every time."

With non-punctual verbs, the combination [NEG + IPFV (positive imperfective)] commonly expresses duration and intensity, as in (32) and (33). Given the semantic nature of the non-punctual verbs, configurations conveying non-durative values, i.e., [NEG + NIPFV], are rather uncommon (34) or grammatically unacceptable (35). A verb like asəm "be jealous", for instance, is mainly associated with positive perfectives, even when occurring in negation structures.

u ttasm-on ši $z a \bar{g}=s$.

NEG be jealous-IPFVa/IPFVb-3MPL NEG of=3sG

"They are not jealous of him."

"They will not be jealous of him."
u ttasam-an
ši $z a \bar{g}=s$.

NEG be jealous-IPFVC-3MPL NEG of=3sG

"They are not really jealous of him/her."
u ttisim-an
ši $z a \bar{g}=s$.

NEG be jealous-NIPFVC-3MPL NEG of $=3 \mathrm{sG}$

"They are not always jealous of him/her."

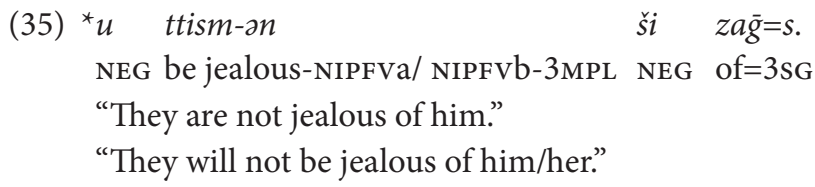

\section{Conclusion}

Given the geographical distance between the two areas in which the innovations discussed have occurred - mainly the Sahara for the Tuareg languages and northern Morocco for Tarifit (see Figure 1) - one can confidently infer that they were not engendered by contact between these languages. Nor do the examined data reveal any possible contact with other non-related languages spoken in the area, such as Arabic, Spanish, French or Hausa. Moreover, although Tuareg and Tarifit show a language-driven derivational mechanism engendering new variants and oppositions in the Berber verbal system, the precise patterns of change and corresponding reorganization of the paradigmatic structure of the verb are significantly divergent. The table below provides an overview of the major differences. 
Table 10. Comparison between Tuareg and Tarifit verbal innovations

\begin{tabular}{|c|c|}
\hline Tuareg (Mali) & Central Tarifit \\
\hline Original imperfectives & Original imperfectives \\
\hline$\uparrow$ & $\uparrow$ \\
\hline Innovated imperfectives & Innovated imperfectives \\
\hline Original perfectives & Original perfectives \\
\hline \multirow{2}{*}{\multicolumn{2}{|c|}{$\begin{array}{c}\uparrow \\
\text { Innovated perfectives }\end{array}$}} \\
\hline & \\
\hline $\begin{array}{c}\text { Innovated imperfectives }=\text { Positive } \\
\text { imperfectives }\end{array}$ & $\begin{array}{c}\text { Innovated imperfectives }=\text { Positive } \\
\text { imperfectives }\end{array}$ \\
\hline & $\uparrow$ \\
\hline & Negative imperfectives \\
\hline $\begin{array}{l}1 \text { new external derivation } \\
\text { procedure }=\text { restricted to this use }\end{array}$ & $\begin{array}{c}\text { Various new reanalyzed internal derivation } \\
\text { procedures = new morphological } \\
\text { combinations mark distinctive semantic } \\
\text { values }\end{array}$ \\
\hline
\end{tabular}

This brings us to the following question: What motivated these system-internal changes in Berber? The data and analysis presented in $\$ 4$ indicate that the innovations in question, and especially those related to the imperfective, were driven mainly by functional parameters.

Tarifit, in particular, displays a hyper-diversification of the morphological marking procedures through new derivations and combinations so as to express fine-tuned semantic distinctions of the imperfective. This language also allows for the innovated pattern [NEG + positive imperfective], which has provoked a number of reanalysis phenomena causing a restructuring of the verbal system. The new morphosyntactic pattern represents a twofold semantic distinction; it expresses habitual values in the case of punctual verbs and durative (intensity) values with non-punctual verbs.

Semantic and pragmatic motivations are also central to the creation of the new morphological variants and their development in Tuareg. Yet, most of the Tuareg languages have been the subject of a simplification of their verbal system (last stage) after several diversification stages, the penultimate of which has introduced certain modality values (Stage V, Adhagh Tuareg). The Tuareg imperfective seems to have followed a cyclical pattern, departing from a one-part aspectual configuration, evolving into a bipartite aspectual configuration followed by a bipartite aspectual/ modal configuration, so as to end in a one-part aspectual configuration again. With the exception of the last stage, which may be the result of formal (i.e., grammatical) cohesion and generalization pressure, all developments have for the most part been functionally determined. 


\section{References}

Basset, André. 1952. La langue berbère. London: Oxford University Press.

Brugnatelli, Vermondo. 2002. "Les thèmes verbaux négatifs du berbère: quelques reflexions". Articles de linguistique berbère. Mémorial Werner Vycichl, ed. by Kamal Naït-Zerrad, 165180. Paris: L'Harmattan.

Cadi, Kaddour. 1987. Système verbal rifain. Forme et sens. Paris: SELAF.

Chaker, Salem. 1989. "Aspect (verbe)". Encyclopédie berbère, 7.971-977.

Chaker, Salem. 1996. "Quelques remarques préliminaires sur la négation en berbère". La négation en berbère et en arabe marocain, ed. by Dominique Caubet and Salem Chaker, 9-22. Paris: L'Harmattan.

Galand, Lionel. 1974. "Introduction grammaticale". Contes touaregs de l'Aïr, ed. by Petites sœurs de Jésus, 13-41. Paris: SELAF.

Galand, Lionel. 1977. "Continuité et renouvellement d'un système verbal: le cas du berbère". Bulletin de la Société de Linguistique de Paris 72:1.275-303.

Galand, Lionel. 2002. Etudes de linguistique berbère. Louvain \& Paris: Peeters.

Heath, Jeffrey. 2005. A Grammar of Tamashek (Tuareg of Mali). Berlin: Mouton de Gruyter. doi:10.1515/9783110909586

Kossmann, Maarten. 1989. "L'inaccompli négatif en berbère". Études et Documents berbères 6.19-29.

König, Crista. 2006. "Marked Nominative in Africa". Studies in Language 30:4.705-782. doi:10.1075/sl.30.4.02kon

Lafkioui Mena. 2006. "La vocalisation des alvéolaires /r/ et /rr/ dans les variétés berbères du Rif”. Studien zur Berberologie/Etudes Berbères 3, ed. by Dymitr Ibriszimow, Rainer Vossen \& Harry Stroomer, 175-184. Köln: Köppe.

Lafkioui, Mena. 2007. Atlas linguistique des variétés berbères du Rif. Köln: Köppe.

Lafkioui, Mena. 2009. "Synchronic and Diachronic Linguistic Variation as an Indicator of Language Change and Diffusion in Tarifit". Studi Magribini (Nuova Serie) 7.65-84.

Lafkioui, Mena. 2011. "How System-Internal Linguistic Factors Indicate Language Change and Diffusion: A Geolinguistic Analysis of Berber Data". Dialectologia et Geolinguistica 19.62-80. doi:10.1515/dig.2011.003

Lafkioui, Mena. Forthcoming. "Dialectology and Linguistic Geography". Handbook of African languages, ed. by Rainer Vossen. Oxford: Oxford University Press.

Lafkioui, Mena \& Maarten Kossmann. 2009. "Les inaccomplis du Tarifit”. L'Amazighe dans l'Oriental et le Nord du Maroc: variations et convergences, ed. by Aïcha Bouhjar \& Hamid Souifi, 101-108. Rabat: Editions IRCAM.

Leguil, Alphonse. 1987. "Les quatre inaccomplis du touareg de l'Adagh". Proceedings of the Fourth Hamito-Semitic Congress (Marburg, 20-22 September 1983), ed. by Herrmann Jungraithmayr \& Walter W. Mueller, 395-406. Amsterdam: John Benjamins. doi:10.1075/cilt.44.22leq

Leguil, Alphonse. 2000. "Une opposition fluctuante en touareg". Etudes berbères et chamitosémitiques. Mélanges offerts à Karl-G. Prasse, ed. by Salem Chaker and Andrzej Zaborski, 257-262. Paris \& Louvain: Peeters.

Mammeri, Mouloud. 1980. Poèmes kabyles anciens. Paris: Maspero.

Matthews, Stephen J. 1990. A Cognitive Approach to the Typology of Verbal Aspect. Los Angeles: University of Southern California dissertation. 
Picard, André. 1959. “Du preterit intensif en berbère”. Memorial André Basset (1895-1956), 107120. Paris: Maisonneuve.

Prasse, Karl-G. 1973. Manuel de grammaire touarègue. Volume: Verbe. Copenhagen: Akademisk Forlag.

Prasse, Karl-G. \& ăgg-Ălbosțan ăgg-Sidiyăn, Ekhya. 1985. Tableaux morphologiques. Dialecte touareg de l'Adrar du Mali (berbère). Copenhagen: Akademisk Forlag.

Schmid, Maureen A. 1980. Co-occurrence Restrictions in Negative, Interrogative, and Conditional Clauses: A Cross-Linguistic Study. Buffalo, NY: SUNY Buffalo dissertation.

Van den Boogert, Nico. 1997. The Berber Literary Tradition of the Sous - With an Edition and Translation of the 'Ocean of Tears' by Muhammad Awzal (d. 1749). Leiden: de Goeie Fund.

Vycichl, Werner. 1953-1955. "Der Umlaut in den Berbersprachen Nordafrikas. Eine Einführung in die berberische Sprachgeschichte". Wiener Zeitschrift für die Kunde des Morgenlandes 52.304-325.

(C) 2018. John Benjamins Publishing Company

All rights reserved 
(C) 2018. John Benjamins Publishing Company All rights reserved 